Biol. Stud. 2019: 13(2); 29-40 • DOI: https://doi.org/10.30970/sbi.1302.603

www.http://publications.Inu.edu.ua/journals/index.php/biology

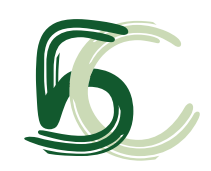

UDC: 577.112 .083

\title{
PROKARYOTIC EXPRESSION AND PURIFICATION OF BIOACTIVE DEFENSIN 2 FROM PINUS SYLVESTRIS L.
}

\author{
N. I. Hrunyk', Yu. I. Shalovylo', Yu. M. Yusypovych', \\ I. I. Roman ${ }^{2}$, I. V. Nesmelova ${ }^{3}$, V. A. Kovaleva ${ }^{1 *}$ \\ ${ }^{1}$ Ukrainian National Forestry University, 103, Gen. Chuprynka, St., Lviv 79057, Ukraine \\ ${ }^{2}$ Ivan Franko National University of Lviv, 1, Saksagansky St., Lviv 79005, Ukraine \\ ${ }^{3}$ University of North Carolina at Charlotte, 9201 University City Blvd., Charlotte 28223, USA \\ *Corresponding author: e-mail: kovaleva@nltu.edu.ua
}

Hrunyk N. I., Shalovylo Yu. I., Yusypovych Yu. M., Roman I. I., Nesmelova I. V., Kovaleva V. A. Prokaryotic expression and purification of bioactive defension 2 from Pinus sylvestris L. Studia Biologica, 2019: 13(2); 29-40 • DOI: https://doi.org/10.30970/sbi.1302.603

Plant defensins are highly stable cysteine-rich peptides consisting of 45-54 amino acid residues with a characteristic conservative $\beta \alpha \beta \beta$ structure stabilized by $4-5$ disulfide bridges. These peptides are key molecules of innate immune system in plants. They inhibit growth of many phytopathogenic fungi, and some of them exhibit antibacterial activity. Defensins also possess other biological functions. The multifunctional properties of the defensin peptides make them attractive candidates for creation of new remedies with antimicrobial properties. Elucidation of nature of the structural and functional relationships in the antimicrobial peptides is an essential step in the development of drugs with activity against pathogens. Previously, we have purified endogenous and recombinant Scots pine defensin 1 (PsDef1) demonstrating high activity against fungi and bacteria. Importantly, PsDef1 is the first defensin from coniferous plants whose NMR structure and properties have been thoroughly investigated, also by the authors of this work. In this study, we presented the expression and affinity purification of recombinant defensin 2 from Pinus sylvestris L. (PsDef2), whose sequence has $90 \%$ identity to PsDef1. We used pET32/ BL21-CodonPlus (DE3)-RIL Escherichia coli expression system to produce large quantities of the recombinant PsDef2 peptide conjugated to thioredoxin (TRX). We found that the highest yield of recombinant protein in its soluble form was obtained at $0.5 \mathrm{mM}$ of isopropyl- $\beta$-D-thiogalactoside (IPTG) concentration for $3 \mathrm{~h}$ of induction at $25^{\circ} \mathrm{C}$. After isolation of TRX-PsDef2 on HisPurNi-NTA resin, the fusion protein was subjected to proteolytic cleavage by enterokinase. PsDef2 was separated from the proteolytic fragments

(C) 2019 N. I. Hrunyk et al.; Published by the Ivan Franko National University of Lviv on behalf of Біологічні Студії / Studia Biologica. This is an Open Access article distributed under the terms of the Creative Commons Attribution License (http://www.budapestopenaccessinitiative.org/ and Creative Commons Attribution 4.0 License), which permits unrestricted reuse, distribution, and reproduction in any medium, provided the original work is properly cited.

ISSN 1996-4536 (print) • ISSN 2311-0783 (on-line) • Біологічні Студії / Studia Biologica • 2019 • Том 13/№2 • С. 29-40 
using the ion exchange on the SP-Sepharose Fast Flow column and a step gradient of $0.05-1 \mathrm{M} \mathrm{NaCl}$. The purity of obtained recombinant PsDef2 was higher than $95 \%$, as verified by $16.5 \%$ SDS-PAGE. The recombinant peptide PsDef2 showed activity against phytopathogenic Fusarium sporotrichiela fungus and Phythophtora gonapodyides oomycete at $5 \mu \mathrm{M}$ concentration. The availability of recombinant PsDef2 gives an option not only to examine its antimicrobial properties but to study its structure by spectroscopic methods (circular dichroism, NMR) in order to establish relationships between the structure and function of pine defensins.

Keywords: defensins, Scots pine, heterologous expression, protein purification, antimicrobial activity

\section{INTRODUCTION}

Plants synthesize various antimicrobial peptides (AMPs), that perform many biological functions. The AMPs as the main components of the plant's innate immune system are ubiquitous and found as host defense against pathogens and pests in diverse organisms ranging from microbes to animals [4, 29]. Defensins form one of several families of plant AMPs [19, 27, 28].

Plant defensins are positively charged cysteine-rich peptides consisting of 45 54 amino acids. They contain a conservative CS $\alpha \beta$ structural motif, consisting of one $\alpha$-helix positioned on the top of three antiparallel $\beta$-sheets stabilized by $4-5$ disulfide bridges [11, 32-34]. Despite a conservative tertiary structure of these peptides, there is a substantial functional variation between them. Based on in vitro assays of isolated peptides, gene expression analysis and studies of transgenic plants, defensins were suggested to be involved in defense against the phytopathogenic organisms (fungi, bacteria, viruses), abiotic stress tolerance to salinity, drought, cold and metals ( $\mathrm{Zn}, \mathrm{Cd})$ and in other, non-defense functions [1, 16, 20, 21, 23, 26, 30]. In addition, plant defensins can affect the fitness of insect pests by inhibiting their digestive enzymes such as proteases and amylases, as well as blocking ion channels [2]. Defensin of Cassia fistula seeds passesses trypsin inhibitory activity [31].

The multifunctional properties of defensin peptides make them attractive candidates for the design of transgenic plants resistant to phytopathogenic organisms or for the development of new drugs with antimicrobial properties [7, 22, 28]. However, to create an integrated platform for producing the antimicrobials or for the design of transgenic plants with specified properties, it is necessary to define the relationship between the structure and function of these molecules.

For detailed structural and functional studies of defensins, a significant amount of active peptides is needed. Purification of defensins from their original source, where their content is very low, is a time-consuming labor-intensive procedure, and the yield of target peptides is low. Therefore, large-scale production of purified active defensins is typically done in heterologous expression systems, usually using Escherichia coli [8]. Previously, we have employed this approach to obtain the recombinant defensin 1 from Scots pine for NMR structural analysis. PsDef1 is the first defensin of the coniferous plants whose NMR structure and properties have been thoroughly investigated $[6,10$, $12,13,15]$. It is worth mentioning that defensins in the pine genome are represented by a multigene family. Previously, we cloned several defensin genes including PsDef2 (GenBank Acc. No. EF 455617.1) whose sequence has $90 \%$ identity to PsDef1 (GenBank

ISSN 1996-4536 (print) • ISSN 2311-0783 (on-line) • Біологічні Студії / Studia Biologica • 2019 • Том 13/№2 • С. 29-40 
Acc. No. EF 455616.1) [14]. We hypothesize that the comparative characteristics of biological activities and features of three-dimensional structures of these two highly homologous pine defensins can reveal which structural motifs are involved in the performance of their functions. Isolation of an active PsDef2 peptide is an essential step in testing this hypothesis.

Here, we addressed the production, purification and subsequent determination of the in vitro antimicrobial activity of PsDef2.

\section{MATERIALS AND METHODS}

Biological material. Escherichia coli strain BL21-CodonPlus(DE3)-RIL genotype B F - ompThsdS ( $r$ B - m B-) dcm + Tetr gal $\lambda$ (DE3) endAHte [argUileYleuW Cam $r$ ] (Stratagene) was used as a host strain for fusion protein TRX-PsDef2 expression. LuriaBertani (LB) medium (w/v), containing $0.5 \%$ yeast extract, $1 \%$ tryptone, and $1 \% \mathrm{NaCl}$, was used for routine bacterial growth and as protein expression medium.

The Fusarium sporotrichiella Bilai fungus and Phytophthora gonapodyides (H.E. Petersen) Buisman oomycete were maintained on potato dextrose agar (PDA) at $25{ }^{\circ} \mathrm{C}$.

Construction of expression vector and protein expression. The construct for recombinant PsDef2 expression was designed by GenScript Biotech Corporation (USA). The construct containing PsDef2 cDNA encoding the mature form of the protein was inserted into pET-32 Ek/LIC vector (Novagen). The vector was used to transform E. coli BL21-CodonPlus(DE3)-RIL competent cells, as described in manufacturer's recommendations.

Isolated colonies were inoculated in LB medium (containing $100 \mu \mathrm{g} / \mathrm{ml}$ ampicillin and $50 \mu \mathrm{g} / \mathrm{ml}$ of chloramphenicol) and shaken overnight at $30^{\circ} \mathrm{C}$. Then, the overnight cell suspension was added to medium with appropriate antibiotics with a ratio of $2 \%(\mathrm{v} / \mathrm{v})$ at $37^{\circ} \mathrm{C}$. To find optimal condition for TRX-PsDef2 protein expression different concentrations of IPTG, as well as time of protein expression were tested. When the culture reached an $\mathrm{OD}_{600}$ of 0.8 , protein expression was induced by the addition of IPTG at three concentrations: $0.1,0.5$ and $1.0 \mathrm{mM}$. Additionally, we tested the effect of temperature $\left(37^{\circ} \mathrm{C}\right.$, $28^{\circ} \mathrm{C}$ and $25^{\circ} \mathrm{C}$ ) on protein expression at four time points: $2,3,4$ and $18 \mathrm{~h}$. To monitor protein expression, non-induced cell culture was used. After finding the optimal conditions, TRX-PsDef2 fusion protein expression was induced with $0.5 \mathrm{mM}$ of IPTG at $25^{\circ} \mathrm{C}$, and cells were harvested after $3 \mathrm{~h}$ post-induction by centrifugation at $10000 \times \mathrm{g}$ for $10 \mathrm{~min}$ at $4{ }^{\circ} \mathrm{C}$. Cells were disrupted in the lysis buffer containing $20 \mathrm{mM}$ Tris- $\mathrm{HCl}, \mathrm{pH} 8.0,300 \mathrm{mM}$ $\mathrm{NaCl}, 25 \mathrm{mM}$ imidazole and $1 \mathrm{mM}$ phenylmethanesulfonyl fluoride (PMSF) by sonication (QSonica Misonix XL-2000). Sonication was performed on ice for $3 \times 1$ min at $50 \%$ amplitude, pulsing at $1 \mathrm{~s}$ on $/ 1 \mathrm{~s}$ off, and with breaks between cycles to prevent heating of the mixture and subsequent centrifugation at $12000 \mathrm{rpm}$ for $20 \mathrm{~min}$ at $4{ }^{\circ} \mathrm{C}$. Total lysates and supernatants were analyzed by $12 \%$ SDS-PAGE performed using Laemmli method [18].

Protein purification and analysis. TRX-PsDef2 fusion protein was purified using HisPurNi-NTA resin (Thermo Fisher, USA). Briefly, the resulting supernatant was added to a $50 \%$ metal affinity sorbent, equilibrated with lysis buffer and incubated for $1 \mathrm{~h}$ at $4{ }^{\circ} \mathrm{C}$. After incubation, the suspension was loaded in the column. Unbound proteins were removed by washing sorbent with $20 \mathrm{mM}$ Tris- $\mathrm{HCl}$ buffer at $\mathrm{pH} 8.0$ with $400 \mathrm{mM}$ $\mathrm{NaCl}$ and $40 \mathrm{mM}$ imidazole. Bound proteins were eluted from the column with $300 \mathrm{mM}$

ISSN 1996-4536 (print) • ISSN 2311-0783 (on-line) • Біологічні Студії / Studia Biologica • 2019 • Том 13/№2 • С. 29-40 
imidazole dissolved in $20 \mathrm{mM}$ Tris- $\mathrm{HCl}, \mathrm{pH} 8.0,300 \mathrm{mM} \mathrm{NaCl}$. Then eluted fractions were analyzed by $12 \%$ SDS-PAGE electrophoresis [18]. Fractions containing recombinant TRX-PsDef2 were pooled and dialyzed against buffer containing $20 \mathrm{mM}$ Tris- $\mathrm{HCl}$, $\mathrm{pH}$ 8.0, $50 \mathrm{mM} \mathrm{NaCl}$. To remove 6His-TRX-tag, TRX-PsDef2 protein was cleaved using enterokinase (New England Biolabs, UK) at $18^{\circ} \mathrm{C}$ for $20 \mathrm{~h}$ in the recommended buffer (20 mM Tris- $\mathrm{HCl}, \mathrm{pH} 8.0,50 \mathrm{mM} \mathrm{NaCl}, 2 \mathrm{mM} \mathrm{CaCl}_{2}$ ).

After cleavage, the digestion mixture was subjected to ion-exchange chromatography on a SP-Sepharose Fast Flow column (GE Healthcare) equilibrated with the $20 \mathrm{mM}$ Tris- $\mathrm{HCl}, \mathrm{pH} 8.0,50 \mathrm{mM} \mathrm{NaCl}$ buffer. After extensive washing using the same buffer, bound proteins were eluted using step gradient from 0.05 to $1 \mathrm{M} \mathrm{NaCl}$ in the $20 \mathrm{mM}$ Tris- $\mathrm{HCl}$ at $\mathrm{pH}$ 8.0. The elution of protein was monitored by absorbance at $280 \mathrm{~nm}$ and confirmed by $16.5 \%$ SDS-PAGE. Fractions containing pure PsDef2, as determined by electrophoresis, with molecular mass about $6 \mathrm{kDa}$ were collected, desalted, and concentrated by ultrafiltration with an Amicon Ultra 3K device (Millipore). Recovered PsDef2 peptide solution was tested against the phytopathogens.

Antimicrobial activity assay. Pathogenic F. sporotrichiella fungus and $P$. gonapodyides oomycete were inoculated on a PDA medium plate $(90 \times 15 \mathrm{~mm}$ Petri dish) and cultured at $25^{\circ} \mathrm{C}$. When each colony reached $4 \mathrm{~cm}$ in diameter, $10 \mu \mathrm{L}$ of $5 \mu \mathrm{M}$ recombinant $P s D e f 2$ aqueous solution were added dropwise on the nutrient medium at $5 \mathrm{~mm}$ from the periphery of the microbial colony. As a blank control, $10 \mu \mathrm{L}$ of sterile distilled water was applied. After the treatment, plates were cultured at $25^{\circ} \mathrm{C}$, and the growth status of each phytopathogen was monitored within 2 days.

\section{RESULTS AND DISCUSSION}

To follow the heterologous expression of Scots pine defensin 2 gene, the cDNA sequence encoding PsDef2 fragment was inserted in the pET-32 Ek/LIC (Novagen), linearized in a frame as a fusion with the thioredoxin. Thioredoxin was selected as a fusion partner, because it helps in maintaining the expressed fusion protein in a soluble fraction and prevents its precipitation in inclusion bodies $[5,17]$.

This construct was transformed into BL21-CodonPlus(DE3)-RIL E. coli cells for expression. Besides fast growth rate and low cost, this strain also offers IPTG-inducible protein expression. It was specially designed to resolve the codon bias problem to improve protein expression by supplying additional copies of specific tRNA genes that are rare in E. coli. The SDS-PAGE analysis of total lysates from induced and non-induced cells revealed the presence of recombinant protein with expected molecular weight of $22.8 \mathrm{kDa}$ (Fig. 1, A). The fusion protein consists of 109 amino acids of thioredoxin protein at the $\mathrm{N}$-terminus and 50 aa corresponding to mature form of PsDef2 at the C-terminus. There is also a 50 aa insert between TRX and PsDef2, that contains cleavable S-tag and His-tag sequences for protein detection and purification along with sites for thrombin and enterokinase proteases. In addition, this analysis has shown that TRXPsDef2 fusion protein is soluble in buffer without any detergents. No peptide bands corresponding to the recombinant protein were observed in the non-induced cultures (Fig. 1, A). We also found that at chosen experimental setup, some TRX-PsDef2 protein was accumulated in inclusion bodies (data not shown). Therefore, we optimized the conditions for achieving maximal yield of soluble TRX-PsDef2. Expression of soluble

ISSN 1996-4536 (print) • ISSN 2311-0783 (on-line) • Біологічні Студії / Studia Biologica • 2019 • Том 13/№2 • С. 29-40 
fusion PsDef2 was optimized by varying IPTG concentrations $(0.1-1 \mathrm{mM})$, temperatures $\left(25^{\circ} \mathrm{C}, 28^{\circ} \mathrm{C}, 37^{\circ} \mathrm{C}\right)$, and time of induction (Fig. 1, B). We found that optimal expression of soluble TRX-PsDef2 was achieved by the induction of bacterial culture with $0.5 \mathrm{mM}$ IPTG for $3 \mathrm{~h}$ at $25^{\circ} \mathrm{C}$.

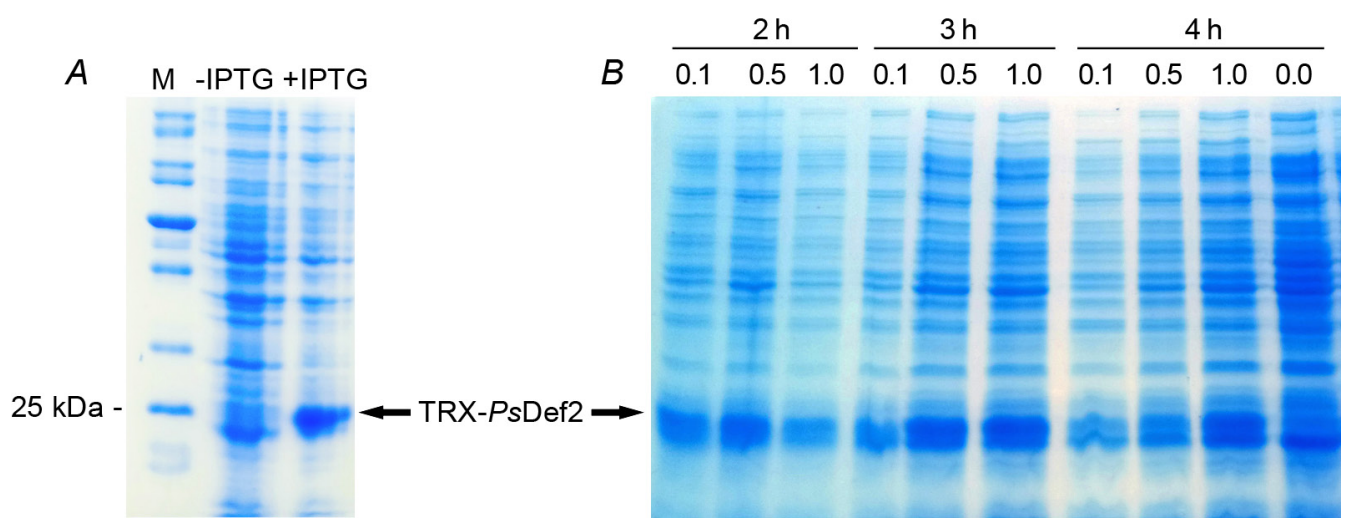

Fig. 1. Expression of TRX-PsDef2 in BL21-CodonPlus(DE3)-RIL cells. (A) SDS-PAGE analysis of soluble protein fractions from E. coli cells transformed with pET-32 Ek/LIC-PsDef2 expression plasmid and incubated in the absence (-) or presence of IPTG (+). (B) Optimization of TRX-PsDef2 expression condition in transformed cells. 2, 3 and $4 \mathrm{~h}$ - time of protein expression induced with $0.1,0.5$ and $1.0 \mathrm{mM}$ of IPTG. $0.0 \mathrm{mM}$ of IPTG is non-induced control. All bacterial test cultures were maintained at $25^{\circ} \mathrm{C}$. The arrow indicates the TRX-PsDef2. M: MW protein markers SM 0661 (Fermentas)

Pис. 1. Експресія TRX-PsDef2 у клітинах штаму BL21-CodonPlus(DE3)-RIL. (A) Електрофоретичний аналіз фрракцій розчинних протеїнів, які виділені з індукованих (+ ІПТГ) і неіндукованих (- ІПТГ) клітин E. coli, трансформованих вектором pET-32 Ek/LIC-PsDef2. (B) Оптимізація умов експресії TRX-PsDef2 у трансформованих клітинах. 2, 3 і 4 год - час культивування індукованих клітин за концентрації ІПТГ: 0,1; 0,5 і 1,0 мМ ІПТГ. 0,0 мМ ІПТГ - контроль, неіндуковані клітини. Всі тести проводили за температури $25^{\circ} \mathrm{C}$. Стрілка вказує на положення TRX-PsDef2 на гелі. М: маркери молекулярної маси протеїнів SM 0661 (Fermentas)

Affinity purification of recombinant TRX-PsDef2 was carried out on HisPurNi-NTA column. As shown in Fig. 2, A (lanes 5-10), fractions eluted from the affinity column by step gradient of imidazole mainly contain a protein of approximately $23 \mathrm{kDa}$ that closely correlates to the predicted molecular mass of the TRX-PsDef2 fusion protein.

Purified preparations of TRX-PsDef2 were pooled and dialyzed against the buffer containing $20 \mathrm{mM}$ Tris- $\mathrm{HCl}, 50 \mathrm{mM} \mathrm{NaCl}$, pH 8,0 (Fig. 2, $B$, line 1). To remove the TPXtag, fusion protein was subjected to proteolytic cleavage according to the manufacturer's recommendation. Initially, we performed a time-course digestion analysis with enterokinase. We found that the complete cleavage of the fusion protein TRX-PsDef2 is achieved after $20 \mathrm{~h}$ of incubation with the protease at room temperature (Fig. 2, B, line 2).

After enzymatic proteolysis, the reaction mixture contained defensin 2 and Histagged proteins. Repeated affinity purification on Ni-NTA resin is often used to remove proteins with His-tag from digestive mixture. According to our and other researchers' results (data not shown), this procedure is not effective for obtaining a desired product of high purity [3]. In our previous studies, Scots pine defensin1 was purified from seedlings, as well as from bacterial cells, using ion-exchange chromatography with a high yield of purity $\geq 95 \%[12,13]$.

ISSN 1996-4536 (print) • ISSN 2311-0783 (on-line) • Біологічні Студії / Studia Biologica • 2019 • Том 13/№2 • С. 29-40 

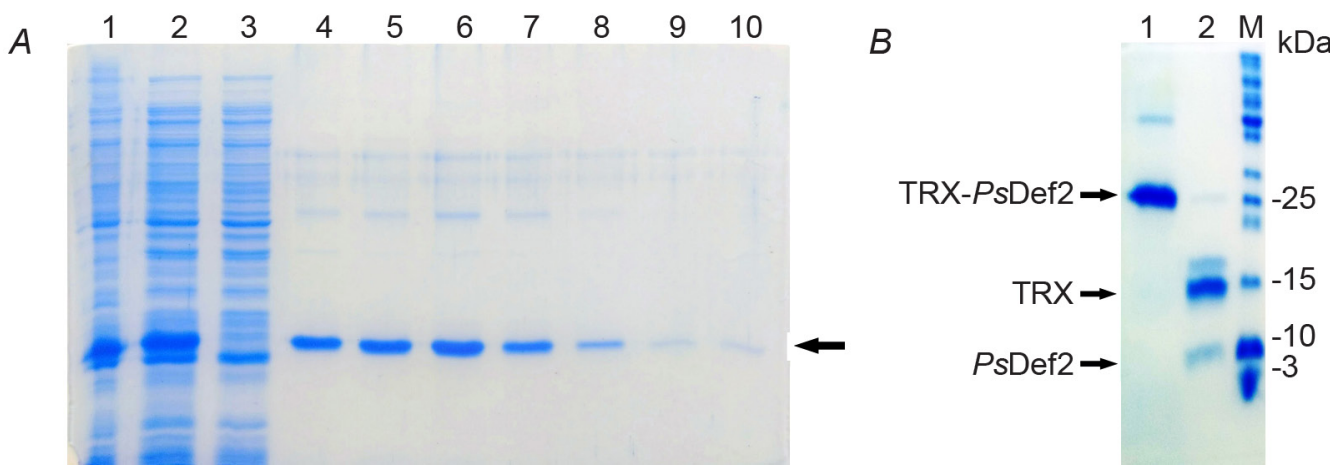

Fig. 2. Affinity purification and cleavage of TRX-PsDef2 fusion protein. (A) Purification of TRX-PsDef2 on HisPurNi-NTA resin. Lane 1: crude protein extract from E. coli cells; lane 2: soluble E. coli proteins; lane 3: flow-through the HisPurNi-NTA; lane 4: proteins bound with metal affinity resin; lane 5: proteins eluted with $0.1 \mathrm{M}$ imidazole; lanes 6-8: proteins eluted with $0.3 \mathrm{M}$ imidazole; lanes 9-10: proteins eluted with $0.7 \mathrm{M}$ imidazole. The arrow indicates the TRX-PSDef2 on the gel. Proteins were separated on $12 \%$ SDS-PAGE. (B) SDS-PAGE analysis of TRX-PsDef2 fusion protein before (lane 1) and after the treatment with enterokinase (lane 2). Proteins were fractioned on the $16.5 \%$ SDSpolyacrylamide gel; M: MW protein markers SM 0661 (Fermentas)

Рис. 2. Афрінне очищення та протеолітичне розщеплення гібридного протеїну TRX-PsDef2. (A) Очищення TRX-PsDef2 на HisPurNi-NTA сорбенті. Доріжка 1: тотальні лізати клітин E. coli; доріжка 2: розчинні протеїни E. coli; доріжка 3: протеїни, що не зв'язались із метал-хелатним аффінним сорбентом; доріжка 4: протеїни, іммобілізовані на Ni-NTA-агарозі; доріжка 5: протеїни, що елюювались 0,1 М імідазолу; доріжки 6-8: протеїни, елюйовані 0,3 М імідазолу; доріжки 9-10: протеїни, елюйовані $0,7 \mathrm{M}$ імідазолу. Стрілка вказує на положення TRX-PsDef2 на гелі. Протеїни фракціонували ДСН-електрофорезом у 12 \%-ному поліакриламідному гелі. (B) Електрофоретичний аналіз гібридного протеїну TRX-PsDef2 до (доріжка 1) та після (доріжка 2) протеолізу ентерокіназою. Протеїни фракціонували у 16,5 \%-ному поліакриламідному гелі; М: маркери молекулярної маси протеїнів SM 0661 (Fermentas)

In order to isolate PsDef2 from the digested mixture, we used ion-exchange chromatography on a SP-Sepharose with a step gradient from 0.05 to $1 \mathrm{M} \mathrm{NaCl}$. The electrophoretic profile of different fractions of the recombinant pine defensin 2 obtained during the purification process can be seen in Fig. 3. Thioredoxin detected in the flowthrough (lane 2). In addition, the enzyme/peptide mixture contained about $5 \%$ of the fusion protein TRX-PsDef2, which was eluted by $0.2-0.3 \mathrm{M} \mathrm{NaCl}$, is shown in lanes 3-4. The presence of PsDef2 was tested electrophoretically, and it was determined that it was contained in fractions that were eluted from the cation exchanger using a high ionic strength buffer from 0.4 to $0.8 \mathrm{M} \mathrm{NaCl}$ (lanes 5-9).

One of the proofs of the correct folding of the recombinant protein expressed in the prokaryotic system is the presence of expected biological activity. As shown earlier, defensin 1 from Scots pine, that is highly-homologous to PsDef2, exhibits high activity against a number of phytopathogenic fungi. We tested the biological activity of Scots pine defensin 2 against $F$. sporotrichiella and Ph. gonapodyides. The assay of antimicrobial activity revealed that PsDef2 manifested growth inhibitory activity against tested phytopathogens. Recombinant Scots pine defensin 2 at $5 \mu \mathrm{M}$ the concentration inhibited hyphal growth and affected the shape of microbial colonies (Fig. 4).

Similar inhibitory activity of recombinant Scots pine defensin 1 against Heterobasidion annosum and Fusarium solani was shown in our previous studies. Therefore, there

ISSN 1996-4536 (print) •ISSN 2311-0783 (on-line) • Біологічні Студії / Studia Biologica • 2019 • Том 13/№2 • С. 29-40 
is a need for further studies of antibacterial and other activities of PsDef2. Since it belongs to the same group of Scots pine defensins as PsDef1 and is similar to PsDef1, it may demonstrate a broader spectrum of biological activity.

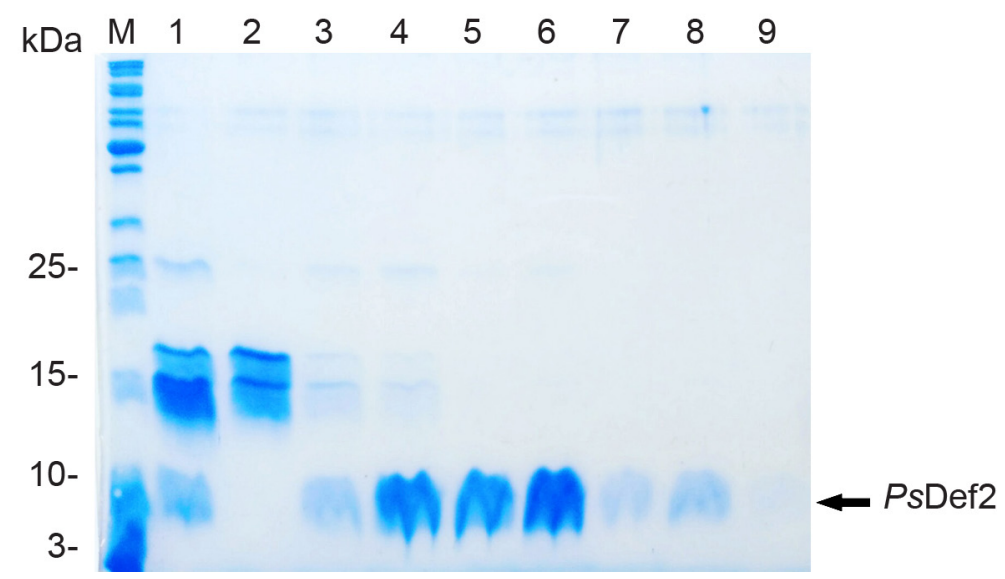

Fig. 3. Purification of PsDef2 on a SP-Sepharose Fast Flow column. Proteins were separated by $16.5 \%$ SDS-PAGE electrophoresis. Lane 1: digestive mixture of cleaved proteins and enterokinase; lane 2: flow through; lanes $3,4,5,6,7,8$ and 9: proteins eluted with a step gradient of $0.2,0.3,0.4,0.5,0.6$, 0.7 and $0.8 \mathrm{M} \mathrm{NaCl}$, respectively. M: MW protein markers SM 0661 (Fermentas)

Рис. 3. Очищення PsDef2 на колонці SP-Sepharose Fast Flow. Протеїни фрракціонували у 16,5 \%-ному поліакриламідному гелі за допомогою ДСН-електрофорезу. Доріжка 1: суміш продуктів протеолізу й ентерокінази; доріжка 2: протеїни, що не зв'язались із катіонітом; доріжки 3, 4, 5, 6, 7, 8 і 9: протеїни, які елюювалися ступінчастим градієнтом 0,2; 0,3; 0,4; 0,5; 0,6; 0,7 і 0,8 M NaCl, відповідно. М: маркери молекулярної маси протеїнів SM 0661 (Fermentas)
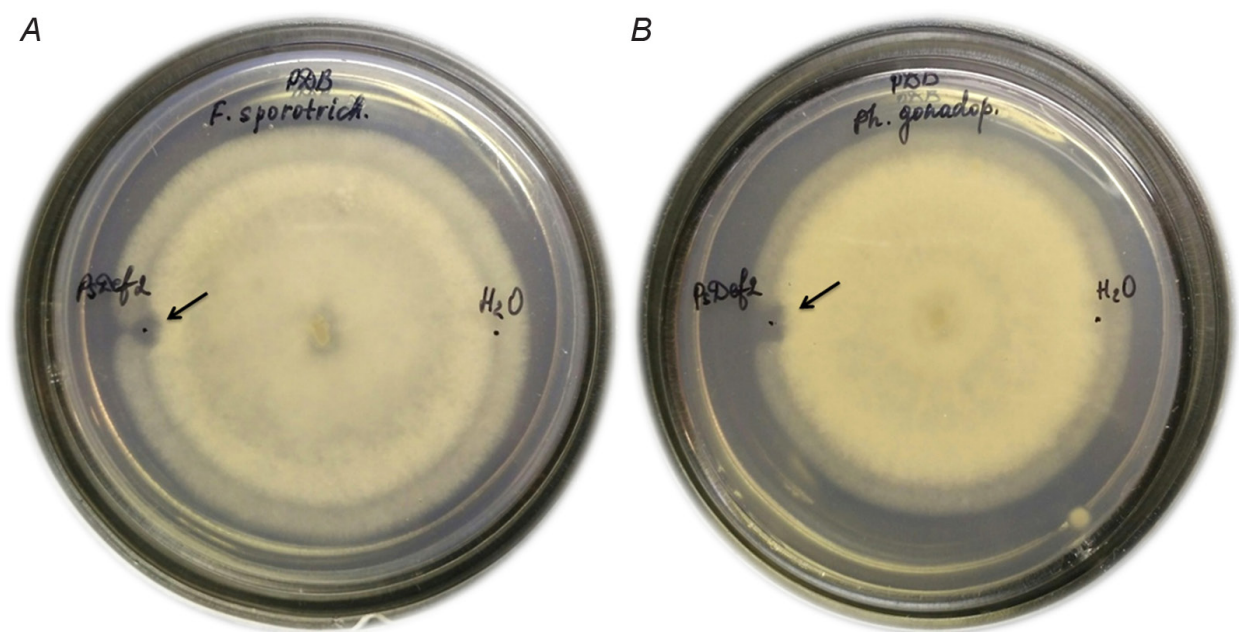

Fig. 4. Inhibitory effect of the PsDef2 peptide at the concentration of $5 \mu \mathrm{M}$ on the phytopathogens' growth (A) Fusarium sporotrichiella; (B) Phytophthora gonapodyides after $48 \mathrm{~h}$ of cultivation. Control - sterile distilled $\mathrm{H}_{2} \mathrm{O}$. Arrows indicate the inhibition zone

Рис. 4. Інгібувальний ефект PsDef2 за концентрації $5 \mu \mathrm{M}$ на ріст фітопатогенів: (A) Fusarium sporotrichiella, (B) Phytophthora gonapodyides після 48 год культивування. Контроль - стерильна дистильована вода. Стрілками вказано зони інгібування

ISSN 1996-4536 (print) • ISSN 2311-0783 (on-line) • Біологічні Студії / Studia Biologica • 2019 • Том 13/№2 • С. 29-40 
The developed protocol resulted in the production of highly homogeneous recombinant defensin 2 that runs on the SDS-PAGE with a predicted molecular mass of $6 \mathrm{kDa}$ (Fig. 3). By optimizing the expression conditions, affinity purification of recombinant TRX-PsDef2 and removing of TRX moiety from the fusion protein by proteolytic cleavage, as well as ion-exchange chromatography on strong cation exchanger, we managed to produce $1 \mathrm{mg}$ of $P s D e f 2$ per liter of bacterial culture. Importantly, the developed protocol results in the production of highly stable and biologically active PsDef2.

The use of a prokaryotic system for the production of bioactive plant defensins is challenged by a correct pairing of four disulfide bridges, which is a characteristic feature of these peptides. To enhance disulfide bond formation in bacteria cytoplasm, active plant defensins were produced as translational fusion proteins with thioredoxin in Origami $E$. coli strain $[9,25]$. Pervieux et al. $(2004)$ used this system for the production of a bioactive defensin from Picea glauca that exhibits $80 \%$ identity to PsDef2 [24]. We found that recombinant $P$ sDef2 possesses antimicrobial activity at $5 \mu \mathrm{M}$ concentration. These results suggest that pET32/BL21 CodonPlus(DE3)-RIL expression system is also efficient for the production of bioactive plant defensins. The availability of recombinant PsDef2 provides a possibility not only to examine its antimicrobial properties but also to study its structure by spectroscopic methods (circular dichroism, NMR) to establish the relationship between the structure and function of pine defensins.

In conclusion, this work describes a successful heterologous expression of plant defensin with antimicrobial activity against phytopathogens. The antimicrobial activity of the recombinant PsDef2 warrants further investigation of its potential in biotechnology applications for protecting plants against infectious diseases.

\section{ACKNOWLEDGEMENTS}

This article is based on work supported by the grants from the Ministry of Education and Science of Ukraine (project No M140) and the U.S. Civilian Research \& Development Foundation (CRDF Global) (grant Nos. FSA3-19-65491-0) for Ukrainian team, and grant Nos. FSA3-19-65490-0 for American research team. Any opinions, findings and conclusions or recommendations expressed in this material are those of the authors and do not necessarily reflect the views of CRDF Global.

1. Ali S., Ganai B.A., Kamili A.N., Bhat A.A., Mir Z.A., Bhat J.A., Tyagi A., Islam S.T., Mushtaq M., Yadav P., Rawat S., Grover A. Pathogenesis-related proteins and peptides as promising tools for engineering plants with multiple stress tolerance. Microbiol. Res., 2018; 212 213: 29-37.

[https://doi.org/10.1016/j.micres.2018.04.008]

2. Bloch C., Jr., Richardson M. A new family of small (5 kDa) protein inhibitors of insect alphaamylases from seeds or sorghum (Sorghum bicolar (L.) Moench.) have sequence homologies with wheat gamma-purothionins. FEBS Lett., 1991; 279: 101-104.

[https://doi.org/10.1016/0014-5793(91)80261-z]

3. Dos Santos I.S., Carvalho Ade O., de Souza-Filho G.A., do Nascimento V.V., Machado O.L., Gomes V.M. Purification of a defensin isolated from Vigna unguiculata seeds, its functional expression in Escherichia coli, and assessment of its insect alpha-amylase inhibitory activity. Protein Expr. Purif., 2010; 71: 8-15.

[https://doi.org/10.1016/j.pep.2009.11.008]

ISSN 1996-4536 (print) • ISSN 2311-0783 (on-line) • Біологічні Студії / Studia Biologica • 2019 • Том 13/№2 • С. 29-40 
4. Egorov T.A., Odintsova T.I., Pukhalsky V.A., Grishin E.V. Diversity of wheat anti-microbial peptides. Peptides, 2005; 26: 2064-2073.

[https://doi.org/10.1016/j.peptides.2005.03.007]

5. Elmorjani K., Lurquin V., Lelion A, Rogniaux H., Marion D. A bacterial expression system revisited for the recombinant production of cystein-rich plant lipid transfer proteins. Biochem Biophys Res Commun, 2004; 316: 1202-1209.

[https://doi.org/10.1016/j.bbrc.2004.02.173]

6. Ermakova E.A., Faizullin D.A., Idiyatullin B.Z. Khairutdinov B.I., Mukhamedova L.N., Tarasova N.B., Toporkova Y.Y., Osipova E.V., Kovaleva V., Gogolev Y.V., Zuev Y.F., Nesmelova I.V. Structure of Scots pine defensin 1 by spectroscopic methods and computational modeling. Int. J. Biol. Macromol., 2016; 84: 142-152.

[https://doi.org/10.1016/j.ijbiomac.2015.12.011]

7. Gao A.G., Hakimi S.M., Mittanck C.A., Wu Y., Woerner B.M., DStark. M., Shah D.M., Liang J.H., Rommens C.M.T. Fungal pathogen protection in potato by expression of a plant defensin peptide. Nature Biotechnology, 2000; 18: 1307-1310.

[https://doi.org/10.1038/82436]

8. Gazzaneo L.R.S., Pandolfi V., de Jesus A.L.S., Crovella S., Benko-Iseppon A. M., de Freitas A.C. Heterologous expression systems for plant defensin expression: examples of success and pitfalls. Curr Protein Pept Sci., 2017; 18 (4): 391-399. [https://doi.org/10.2174/1389203717666160625070414]

9. Kaomek M., Mizuno K., Fujinira T., Sriyotha P., Cairna J.R.K. Cloning, expression and characterization of an antifungal chitinase from Leucaena leucocephla De Wit. Biosci. Biotechnol. Biochem., 2003; 67: 667-676.

[https://doi.org/10.1271/bbb.67.667]

10. Khairutdinov B.I., Ermakova E., Yusypovych Y.M., Bessolicina E.K., Tarasova N.B., Toporkova Y.Y., Kovaleva V., Zuev Y.F., Nesmelova I.V. NMR structure, conformational dynamics, and biological activity of PsDef1 defensin from Pinus sylvestris. Biochimica et biophysica acta. Proteins and proteomics, 2017; 1865(8): 1085-1094.

[https://doi.org/10.1016/j.bbapap.2017.05.012]

11. Kobayashi Y., Sato A., Takashima H., Tamaoki H., Nishimura S., Kyogoku Y., Ikenaka K., Kondo T., Mikoshiba K., Hojo H., Aimoto S., Moroder L. A new $\alpha$-helical motif in membrane active peptides. Neurochem. Internat, 1991; 18: 525-534.

[https://doi.org/10.1016/0197-0186(91)90151-3]

12. Kovaleva V.A., Kiyamova R.G., Cramer R., Krynytskyy H. T., Gout I.T., Filonenko V.V., Gout $R$. Purification and molecular cloning of antimicrobial peptides from Scots pine seedlings. Peptides, 2009; 30(12): 2136-2143.

[https://doi.org/10.1016/j.peptides.2009.08.007]

13. Kovaleva V.A., Krynytskyy H.T., Gout I.I., Gout R.T. Recombinant expression, affinity purification and functional characterization of Scots pine defensin 1. Appl. Microbiol. Biotechnol., 2011; 89(4): 1093-1101.

[https://doi.org/10.1007/s00253-010-2935-2]

14. Kovalyova V.A., Gout I.T. Molecular cloning and characterization of Scotch pine defensin 2. Cytology and Genetics, 2008; 42(6): 408-412.

[https://doi.org/10.3103/S0095452708060091]

15. Kovalyova V.A., Gout I.T., Kiyamova R.G., Filonenko V.V., Gout R.T. Cloning and analysis of defensin 1 cDNA from Scots pine. Biopolymers and Cell, 2007; 23(5): 398-404.

[https://doi.org/10.7124/bc.000779]

16. Lacerda A.F., Vasconcelos É.A.R., Pelegrini P.B., Grossi de Sa M.F. Antifungal defensins and their role in plant defense. Frontiers in Microbiology, 2014; 5: 116.

[https://doi.org/10.3389/fmicb.2014.00116] 
17. La Vallie E.R., Di Blasio-Smith E.A., Collins-Racie L.A., Lu Z., McCoy J.M. Thioredoxin and related proteins as multifunctional fusion tags for soluble expression in E. coli. Methods MolBiol, 2003; 205: 119-140.

[https://doi.org/10.1385/1-59259-301-1:119]

18. Laemmli U.K. Cleavage of structural proteins during the assembly of the head of bacteriophage T4. Nature, 1970; 227: 680-685.

[https://doi.org/10.1038/227680a0]

19. Lay F.T, Anderson M.A. Defensins - components of the innate immune system in plants. Curr. Protein Pept Sci., 2005; 6: 85-101. [https://doi.org/10.2174/1389203053027575]

20. Luo J.S., Gu T.Y., Yang Y., Zhang Z.H. A non-secreted plant defensin AtPDF26 conferred cadmium tolerance via its chelation in Arabidopsis. Plant Molecular Biology, 2019; 100(4-5): 561-569.

[https://doi.org/10.1007/s11103-019-00878-y]

21. Mirouze M., Sels J., Richard O., Czernic P., Loubet S., Jacquier A., Francois I.E., Cammue B.P., Lebrun M., Berthomieu P., Marques L. A putative novel role for plant defensins: a defensin from the zinc hyper-accumulating plant, Arabidopsis halleri, confers zinc tolerance. Plant J., 2006; 47: 329-42.

[https://doi.org/10.1111/j.1365-313X.2006.02788.x]

22. Nordström R., Malmsten M. Delivery systems for antimicrobial peptides. Adv. Colloid Interface Sci. 2017; 242: 17-34.

[https://doi.org/10.1016/j.cis.2017.01.005]

23. Parisi K., Shafee T.M.A., Quimbar P., vander Weerden N.L., Bleackley M.R., Anderson M.A. The evolution, function and mechanisms of action for plant defensins. Semin. CellDev. Biol., 2018; 5(6): 1-12.

[https://doi.org/10.1016/j.semcdb.2018.02.004]

24. Pervieux I., Bourassa M., Laurans F., Hamelin R.C., Seguin A. A spruce defensin showing strong antifungal activity and increased transcript accumulation after wounding and jasmonate treatments. Physiological and Molecular Plant Pathology, 2004; 64: 331-341. [https://doi.org/10.1016/j.pmpp.2004.09.008]

25. Picart P., Pirttilä A.M., Raventos D. Identification of defensin-encoding genes of Picea glauca: characterization of PgD5, a conserved spruce defensin with strong antifungal activity. BMC Plant Biol., 2012; 12: 180.

[https://doi.org/10.1186/1471-2229-12-180]

26. Sher Khan R., Iqbal A., Malak R., Shehryar K., Attia S., Ahmed T., Khan M.A., Arif M., Mii M. Plant defensins: types, mechanism of action and prospects of genetic engineering for enhanced disease resistance in plants. 3 Biotech., 2019; 9: 192-204.

[https://doi.org/10.1007/s13205-019-1725-5]

27. Sinha M., Singh R.P., Kushwaha G.S., Iqbal N., Singh A., Kaushik S., Kaur P., Sharma S., Singh T.P. Current overview of allergens of plant pathogenesis related protein families. Sci. World J., 2014; 2014: 543195.

[https://doi:10.1155/2014/543195]

28. Sinha R, Shukla P. Antimicrobial Peptides: Recent insights on biotechnological interventions and future perspectives. Protein Pept Lett., 2019; 26 (2): 79-87.

[https://doi.org/10.2174/0929866525666181026160852]

29. Sitaram N. Antimicrobial peptides with unusual amino acid compositions and unusual structures. Curr. Med. Chem., 2006; 13: 679-696.

[https://doi.org/10.2174/092986706776055689]

30. Skolotneva E. S., Salina E. A. Resistance mechanisms involved in complex immunity of wheat against rust diseases. Vavilovskii Zhurnal Genetiki i Selektsii = Vavilov Journal of Genetics and Breeding, 2019; 23(5): 542-550. (In Russian)

[https://doi.org/10.18699/VJ19.523]

ISSN 1996-4536 (print) • ISSN 2311-0783 (on-line) • Біологічні Студії / Studia Biologica • 2019 • Том 13/№2 • С. 29-40 
31. Wijaya R., Neumann G.M., Condron R., Hughes A.B., Polya G.M. Defense proteins from seed of Cassia fistula include a lipid transfer protein homologue and a protease inhibitory plant defensin. Plant Sci., 2000; 159: 243-255. [https://doi.org/10.1016/S0168-9452(00)00348-4]

32. Yount N. Y., and Yeaman M. R. Multidimensional signatures in antimicrobial peptides. Proc. Natl. Acad. Sci. U.S.A., 2004; 101: 7363-7368. [https://doi.org/10.1073/pnas.0401567101]

33. Yount N.Y., Andrés M.T., Fierro J.F., Yeaman M.R. The gamma-core motif correlates with antimicrobial activity in cysteine-containing kaliocin-1 originating from transferrins. Biochim. Biophys. Acta, 2007; 1768: 2862-2872. [https://doi.org/10.1016/j.bbamem.2007.07.024]

34. Zhu S., Gao B., Tytgat J. Phylogenetic distribution, functional epitopes and evolution of the CSab superfamily. Cell Mol. Life Sci., 2005; 62: 2257-2269.

[https://doi.org/10.1007/s00018-005-5200-6]

\title{
ПРОКАРІОТИЧНА ЕКСПРЕСІЯ ТА ОЧИЩЕННЯ БІОАКТИВНОГО ДЕФЕНЗИНУ 2 PINUS SYLVESTRIS L.
}

\author{
Н. І. Груник ${ }^{1}$, Ю. І. Шаловило ${ }^{1}$, Ю. М. Юсипович1, \\ І. І. Роман ${ }^{2}$, І. В. Несмєлова ${ }^{3}$ В. А. Ковальова ${ }^{1 \star}$ \\ ${ }^{1}$ Національний лісотехнічний університет України, \\ вул. Генерала Чупринки, 103, Львів 79057, Україна \\ 2 Львівський національний університет імені Івана Франка, \\ вул. Грушевського, 4, Львів 79005, Україна \\ *Кореспондуючий автор: e-mail: kovaleva@nltu.edu.ua
}

3 Університет Північної Кароліни, 9201, Бульвар університету, Шарлот 28223, США

Рослинні дефензини - це багаті на цистеїн пептиди із 45-54 амінокислотних залишків, які характеризуються консервативною структурою $\beta \alpha \beta \beta$, стабілізованою 4-5 дисульфрідними зв'язками. Ці пептиди є одними із ключових молекул природної імунності рослин. Вони пригнічують ріст широкого кола фітопатогенних грибів, а деякі $з$ них характеризуються антибактеріальною активністю. На додаток, дефензини виконують й інші біологічні функції, не пов'язані зі захистом рослин. Саме мультифункціональні властивості дефензинів роблять їх перспективними кандидатами для створення нових препаратів із антимікробними властивостями. Для дизайну таких сполук важливо з'ясувати зв'язки між структурою і біологічною активністю молекул. Раніше ми отримали ендогенний та рекомбінантний дефензин 1 сосни звичайної (PsDef1), який проявив високу активність проти фрітопатогенних грибів і бактерій. Це $є$ перший дефензин хвойних рослин, структура якого була досліджена методом ЯМР, зокрема, авторами цієї роботи. У цій статті нами представлено гетерологічну експресію й очищення рекомбінантного дефензину 2 Pinus sylvestris L. (PsDef2), амінокислотна послідовність якого ідентична до такої PsDef1 на $90 \%$. Використання системи експресії pET32/BL21-CodonPlus (DE3)-RIL дало можливість отримати дефензин 2, кон'югований із тіоредоксином (TRX), у розчинній формі. Встановлено, що найвищий вихід розчинного TRX-PsDef2 досягається за індукції трансформованих клітин 0,5 мМ ізопропіл- $\beta$-D-1-тіогалактопіранозидом

ISSN 1996-4536 (print) • ISSN 2311-0783 (on-line) • Біологічні Студії / Studia Biologica • 2019 • Том 13/№2 • С. 29-40 
(IПTГ) і культивуванням їх протягом 3 год за температури $25^{\circ} \mathrm{C}$. TRX-PsDef2 очищено на HisPurNi-NTA колонці. Гібридний протеїн розщеплено ентерокіназою. PsDef2 виділено зі суміші продуктів протеолізу й ентерокінази за допомогою іонообмінної хроматографії SP-Sepharose Fast Flow та ступінчастого градієнта концентрації $\mathrm{NaCl}$ (0,05-1 M). Чистота отриманого рекомбінантного PsDef2 була вищою за 95 \%, що перевірено за допомогою електрофорезу у 16,5 \% ДСН-ПААГ. Встановлено, що рекомбінантний пептид PsDef2 має активність щодо фітопатогенного гриба Fusarium sporotrichiella й ооміцета Phythophtora gonapodyides за концентрації 5 мкM. Отримання рекомбінантного PsDef2 відкриває можливість не тільки вивчити його біологічну активність, але й дослідити його структуру спектроскопічними методами (круговим дихроїзмом і ЯМР), що дасть змогу встановити зв'язки між структурою та функцією дефензинів сосни.

Ключові слова: дефензини, сосна звичайна, гетерологічна експресія, очищення протеїну, антимікробна активність

Одержано: 17.10.2019

ISSN 1996-4536 (print) • ISSN 2311-0783 (on-line) • Біологічні Студії / Studia Biologica • 2019 • Том 13/№2 • С. 29-40 